\title{
EFFECT OF SOME PLANT EXTRACTS ON CONTROLLING SUGAR BEET DAMPING-OFF AND ROOT ROT DISEASES CASUED BY Rhizoctonia Solani KÜHN . Gouda M .I . \\ Plant Pathology Research Institute ARC,Giza-Egypt.
}

\begin{abstract}
In vitro, The effect of six plant originated extracts had been studied on reducing the linear growth of Rhizoctonia solani Kuhn,the causal pathogen of damping-off and root rot disease of sugar beet plants. Under greenhouse and field conditions, the effect of improving the number of survived seedling and root rot was also studied. Extracts of Ammi visnaga (Picktooth) (seeds), Boughainvillae spectabilisWilld.(Boughainvillia) were superior than the other materials in reducing the pre-and post emergence damping-off and root rot of sugar beet as well as the disease severity.The rest materials were less effective in decreasing the disease incidince. At the same time, increasing the concentration of the tested materials significantly reduced the linear growth of $R$. solani. However, the fungicide Rizolex T. 50 was more effective than plant the extracts. Plant extracts were more effective and increased morpholigical characters, plant hieght and Leaf area per plant, also increasing the yield compenents, total soluble solids (TSS), sucrose percent in root and sugar purity. Chemical components within seeds of A.visnaga were fractinated into three fractions. These fractions in addition to Khellin (active component in seeds) showed that fraction (3) and Khellin were the only ones which have the capability to check the fungal growth of the pathogen, also visnagin and Khellin are the chemical components responsible for inhibatory effect of seeds of A.visnaga against sugar beet infecting fungi. The fungicide Rizolex T.50 was used for comparative studies in controlling these diseases.
\end{abstract}

\section{INTRODUCTION}

Sugar beet (Beta vulgaris L.) has become one of the most economically important crops in Egypt. This crop is liable to be attacked by certain soil-borne pathogens at all stages of growth causing pre-and postemergance damping-off, as well as various degrees of root-rots. Rhizoctonia solani. was considered among the most destructive diseases affecting yield crop in Egypt (El-Abyad et al., 1992 ; El-Kazzaz et al., 1999 ; El- Kholi 2000 and El-Kazzaz et al., 2003 ).

The present work aimed to study the effect of certain plant extracts on controlling sugar beet damping-off and root rot disease casued by Rhizoctonia solani.

\section{MATERIALS AND METHODS}

Plant extracts : Different plant parts (Roots, Leaves and Seeds) of Six higher plant species from 6 different plant families namely, Trigonella foenum-graecum L. (Fenugreek), Ammi visnaga L. (Pick tooth), Glycyrrhiza glabra L. (Liquarice), Eucalybtus globulus Labill. (Blue gume), Boughainvillae 
spectabilis. Willd. (Boughainvilla) and Salix purpurea L. (Purpurea willow) were selected for the present study. These plants were identified according to the taxonomic characters described by Chiej (1988) as well as by the help of Dept.Weeds Res., Field Crops Res. Insitute, ARC, cairo

Preparation of plant extracts : According to Mangamma and Sreeramulu (1991), fresh plant materials were collected, washed with running tap water , then with distilled water and left in air to dry at room temperature.The dried plant materials were ground into fine powder. The powder was extracted using ethyl alcohol and acetone $(1: 1 \mathrm{v} / \mathrm{v})$. One hundred grams from the finally prepared powder of plant parts were soaked in $200 \mathrm{ml}$ of the solvent and shaked for $48 \mathrm{~h}$. then blended for 5 minutes and filtrated through anhydrous sodium sulfate by using Wattman No.1 filter papers. The solvent was evaporated under reduced pressure and the crude extract was stored in amber bottles and kept in refrigerator at $(5 \pm 1)^{\circ} \mathrm{C}$ until needed.

In vitro experiment : Plant extracts mixed with melted PDA just before solidification at $48-50{ }^{\circ} \mathrm{C}$ at the required concentrations $(1000,1500$ and $2000 \mathrm{ppm})$ for plant extracts and poured into Petri dishes $(9 \mathrm{~cm}$ in diameter). In another treatment, fungicide namely Rizolex T-50 was incorporeated into PDA by the same method mentioned before. Check treatment was PDA without any additives. Plates were inoculated at the center with culture discs (5 $\mathrm{mm}$ in diameter) of fungal growth of $R$. solani and incubated at $28^{\circ} \mathrm{C}$. Radial growth of $R$. solani was determined by measuring colony diameter in each of four replicate plates. Percentage of reduction in colony diameter was calculated for each treatment.

Preparation of the inoculum : Glass bottles of $500 \mathrm{ml}$ capacity containing $190 \mathrm{gm}$ clean moistened sand and $10 \mathrm{gm}$ corn meal were autoclaved for 30 minutes at $1.5 \mathrm{~atm}$., then inoculated with the tested fungus and incubated at $28-30^{\circ} \mathrm{C}$ for 15 days.Sterilized- $35 \mathrm{~cm}$ diameter clay pots were used in this experiment. Pots were filled with sterilized sandy-loam soil $(1: 2 \mathrm{w} / \mathrm{w})$. Pot soil was infested with the fungal inoculum at the rate of $2 \%$ of the soil weight. Infested soil was mixed thoroughly and moistened with water every other day for one week before planting to ensure the distribution and uniformity of the pathogen.

Greenhouse experiments : Plant extracts were evaluated for their efficiency against damping-off and root-rot diseases caused by $R$. solani under greenhouse conditions. Seeds were soaked into a concentration of $2000 \mathrm{ppm}$ of each of the plant extracts under study for 8 hours before planting. Sterilized-35 $\mathrm{cm}$ diameter clay pots were used in this experiment. Pots were filled with sterilized sandy-loam soil $(1: 2 \mathrm{w} / \mathrm{w})$. Potted soil was infested with the fungal inoculum at the rate of $2 \%$ of the soil weight. Infested soil was mixed thoroughly and moistened with water every other day for one week befor planting to ensure the distribution and uniformity of the pathogen. Sugar beet seeds of Kawmera cv. were surface sterilized by immersing in $3 \%$ sodium hypochlorite solution for 3 minutes, followed by 
ethanol $70 \%$ for 2 minutes, then insed in three changes of sterilized water. Seeds were cultivated in $R$. solani -infested soil (15 seeds/pot). In another treatment, seeds of the same sugar beet cultiver were treated with Rizolex $\mathrm{T}-50$ at the rate recommended dose $(2.5 \mathrm{Kg})$, then sown in infested soil.Three replicate pots (No.35) were used and uninfested soil acted as control. Disease readings were taken $15,45 \& 150$ days after planting for seed rotting pre, post emergence damping-off and root rot respectively. Root yield per plant and yield losses due to infection were also estimated at harvest time (150 days of planting). Yield component i.e. total soluble solids (TSS) , sucrose percent and sugar purity were also estimated.TSS was estimated in fresh roots using the manual refractometer according to $\mathrm{Mc}$ Ginnis 1982. Sucrose percent was estimated according to A. O. A. C. , 1990. Purity percent was calculated by dividing the sucrose percent by TSS. Also plant height, leaf area and leaf dry weight were estimated after 150 days of planting. Leaf area (mm2) was determined using LI-3100 area meter.

Chemical fractionation of seeds of A.visnaga: To evaluate chemical extracts from A.visnaga seeds versus the major sugar beet root pathogens, the powdered A.visnaga seeds were extracted in a soxhlet apparatus with diethyl-ether. The ether extract was concentrated and kept in a refrigerator for few days. The upper green oily layer was removed (fraction I) by filtration with suction. The fat was removed by dissolving in petroleum ether (fractions II). Methyl alcohol was used to solve the remaining solid product from the last step (fraction III). This extract contains the active substance within the seeds known as visnagin. The remaining purified crystals are the active ingredient known as khellin.

Field experiments: These experiments were performed in the expreimental farm which had a back history of heavey infestation at Sakha Res. Stn.(Kafr El-Sheikh) in two successive seasons i.e. 2002-2003 and 20032004. Randomized complete block design with three replicate plots each of $10.5 \mathrm{~m} 2$.Evaluation of pre and post emergence damping- off was taken after 15 and 45 days of planting respectively. Root rots were estimated and recorded along with the yield per plot at harvest time (about 200 days of planting). Disease readings were taken and recorded as percentage of infection and disease severity at harvest, according to the 1-10 grades of Grainger scale (Grainger 1949)

Statistical analysis : Duncan's multiple range test (DMRT) used Irristat Michigan State Univ., USA,1993.

\section{Results}

Results shown in Tables (1) and illusterated Fig. (1) indicate that all experimented materials were positively effective in reducing the linear growth $R$. solani,in general. The effect was obviously increased by increasing the concentration of plant extracts from 1000 to $2000 \mathrm{ppm}$. The obtained data show that the extracts from seeds of $A$. visnaga (pick tooth) 


\section{Gouda M. I.}

followed in retarding the linear growth of the pathogen after the fungicide, RizolexT50.On the contrary, the extract of $S$. purpurea (purpurea willow) leaves and $E$. globulus (blue gum) leaves, showed the least effective in this respect.

Table (1): Effect of certain plant extracts on linear growth of $R$. solani

\begin{tabular}{|c|c|c|c|c|c|c|c|c|}
\hline \multirow{3}{*}{ Plant extracts } & \multicolumn{6}{|c|}{ Concentrations } & \multirow{2}{*}{\multicolumn{2}{|c|}{ Mean }} \\
\hline & \multicolumn{2}{|c|}{1000 ppm } & \multicolumn{2}{|c|}{1500 ppm } & \multicolumn{2}{|c|}{2000 ppm } & & \\
\hline & L.G. & R. & L.G. & R. & L.G. & R. & L.G. & R. \\
\hline 1- Trigonella foenum-graecum L. & $8.92 b$ & 0.87 & $8.85 \mathrm{~b}$ & 1.67 & $8.47 \mathrm{c}$ & 5.89 & 8.74 & 2.89 \\
\hline 2- Ammi visna & $7.68 \mathrm{~d}$ & 14.67 & $6.45 \mathrm{c}$ & 28.33 & $5.65 \mathrm{~d}$ & 37.22 & 6.59 & 26.74 \\
\hline 3- Glycyrrhiza & $6.62 \mathrm{e}$ & 26.44 & $6.13 \mathrm{~d}$ & 31.89 & $5.43 \mathrm{e}$ & 39.67 & 6.06 & 32.66 \\
\hline 4- Eucalyptus gl & $9.00 \mathrm{a}$ & 0.00 & $9.00 \mathrm{a}$ & 0.00 & $8.97 \mathrm{a}$ & 0.33 & 8.99 & 0.11 \\
\hline 5- Boughoinvillae spectabilis willd. & $8.77 \mathrm{c}$ & 2.55 & $6.03 \mathrm{e}$ & 33.00 & $4.65 \mathrm{f}$ & 48.33 & 6.48 & 27.96 \\
\hline 6- Ammi visnaga L. ( seeds) . & $5.62 f$ & 37.55 & $3.48 \mathrm{f}$ & 61.33 & $2.95 \mathrm{~g}$ & 67.22 & 4.02 & 61.18 \\
\hline 7- Salix purpurae L. & $9.00 \mathrm{a}$ & 0.00 & $8.82 b$ & 1.89 & $8.63 \mathrm{~b}$ & 4.11 & 8.82 & 0.98 \\
\hline 8- Rizolex T-50. & $0.60 \mathrm{~g}$ & 93.33 & $0.60 \mathrm{~g}$ & 93.33 & $0.60 \mathrm{~h}$ & 93.33 & 0.60 & 93.33 \\
\hline 9- Control & $9.00 \mathrm{a}$ & 0.00 & $9.00 \mathrm{a}$ & 0.00 & $9.00 \mathrm{a}$ & 0.00 & 9.00 & 0.00 \\
\hline
\end{tabular}

Means followed by the same letter are not significantly different at $5 \%$ level by DMRT.

L.G. = Fungal linear growth $(\mathrm{cm})$. R. = reduction in colony diameter $\%$.

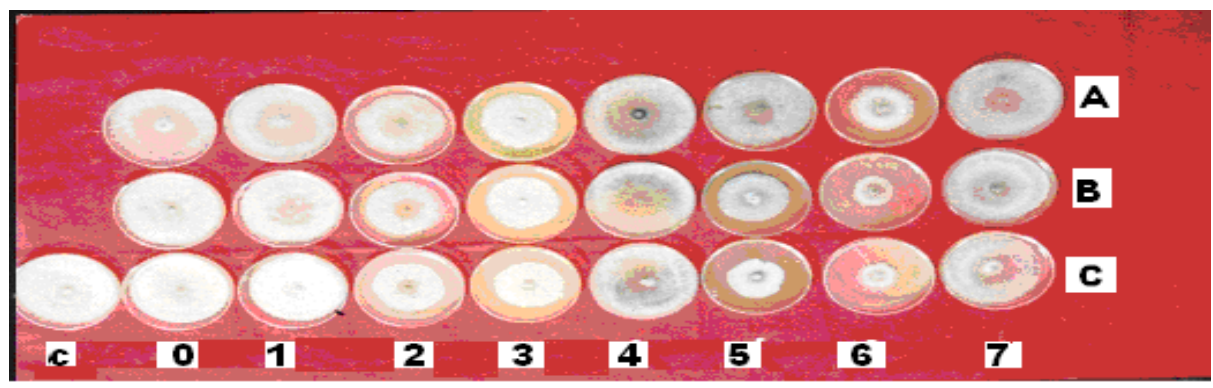

Fig.1: Effect of the tested Plant extracts on linear growth of $R$. solani in PDA-plates at the concentration of 1000 (A), 1500 (B), 2000 ppm. (C). 1- T. Foenum-greacum. 2- A. visnaga (leaves). 3- G. glabra. 4- E. globules. 5- B. spectabilis. 6- A. visnaga (Seeds). 7- S. purpura.

Greenhouse experiments : Pot experiments were carried out in order to find out the effect of plant extracts on the disease incidence of sugar beet damping-off and root rot caused by $R$. solani. Weight of roots as well as the yield components expressed as percentages of the total soluble solids (TSS)\& sucrose, purity degree of sucrose and sugar losses due to the effect of root infection was studied.

Data presented in Table (2) show that all tested plant extracts have significant effect in improving the number of survived seedlings due to controlling the pre-\& post-emergance damping off. Extracts of A.visnaga 
(seeds)followed by B. spectabilis \& G. glabra and A.visnaga (leaves) were highly effective in reducing damping-off and root rot as well as the severity of rot diseases of sugar beet.The rest materials were less effective in decreasing the disease incidence, generally. Similar results were obtained from both seasons of experimentation.

Parameters of plant growth were studied in the same two growing seasons and data are shown in Table (3). Results indicate that all plant extracts improved plant growth expressed as plant height, leaf area, and leaf dry weight. However, A.visnaga and B.spectabilis, in particular were as effective as Rhizolex T.50 in enhancing the plant growth comparable to the other matters. This is correct in both seasons of experimentation.

Root fresh weight was found to be increased by decreasing the disease incidence of root rot incited by $R$. solani due to treating beet seeds with any of the tested plant extracts (Table, 4). Ammi visnaga seed or leaf extracts caused the highest degree of increasing leaf dry weight, total soluble sugars (TSS), sucrose percent in roots and sugar purityin general. While, S.purpurea \& T.foenum-graecum Which showed the highest degree of infection to roots and disease severity were the least effective in this respect

Table 2: Effect of plant extracts used for soaking seeds on the incidence of sugar beet damping- off, root rot and disease severity caused by $R$. solani, greenhouse, during 2002-2003 and 2003-2004 seasons .

\begin{tabular}{|c|c|c|c|c|c|c|}
\hline \multirow[b]{2}{*}{ Treatment } & \multicolumn{2}{|c|}{ Damping-off } & \multirow[b]{2}{*}{ 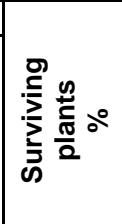 } & \multicolumn{2}{|c|}{ Root rot } & \multirow[b]{2}{*}{ 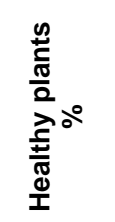 } \\
\hline & ఏ & 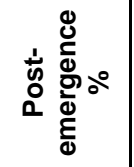 & & 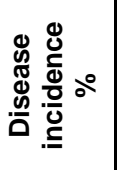 & 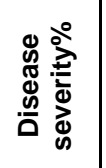 & \\
\hline \multicolumn{7}{|l|}{$2002-2003$ season } \\
\hline 1- Trigonella foenum-graecum L. & $59.26 \mathrm{e}$ & $14.81 d$ & $23.22 \mathrm{~d}$ & $33.33 c$ & $2.00 c$ & $66.67 d$ \\
\hline 2- Ammi visnaga L. ( leaves ) & $33.37 d$ & $22.22 \mathrm{e}$ & $44.11 \mathrm{e}$ & $0.00 \mathrm{a}$ & $0.00 \mathrm{a}$ & $100.00 f$ \\
\hline 3- Glycyrrhiza glabra L. & $33.35 d$ & $22.22 \mathrm{e}$ & $44.44 \mathrm{e}$ & $22.22 b$ & $1.00 \mathrm{~b}$ & $84.46 \mathrm{e}$ \\
\hline 4- Eucalyptus globulus labill. & $74.08 f$ & $14.78 d$ & $14.74 \mathrm{c}$ & $66.67 d$ & $3.67 d$ & $33.33 c$ \\
\hline 5-Boughoinvillae spectabilis willd. & $40.74 d$ & $7.41 \mathrm{c}$ & $48.15 e$ & $22.22 b$ & $1.67 \mathrm{bc}$ & $84.45 e$ \\
\hline 6- Ammi visnaga L. ( Seeds) & $18.85 c$ & $11.11 c$ & $70.37 f$ & $0.00 \mathrm{a}$ & $0.00 \mathrm{a}$ & $100.00 \mathrm{~g}$ \\
\hline 7- Salix purpura L. & $77.79 f$ & $14.81 d$ & $7.37 \mathrm{~b}$ & $77.78 \mathrm{e}$ & $3.50 \mathrm{~d}$ & $22.22 b$ \\
\hline 8- Rizolex T-50. & $0.00 \mathrm{a}$ & $7.41 \mathrm{c}$ & $96.30 \mathrm{~h}$ & $0.00 \mathrm{a}$ & $0.00 \mathrm{a}$ & $100.00 \mathrm{~h}$ \\
\hline 9- Control : Infested & $92.59 \mathrm{~g}$ & $3.67 \mathrm{~b}$ & $3.67 a$ & $82.22 f$ & $9.17 \mathrm{e}$ & $11.11 \mathrm{a}$ \\
\hline 10- Control : Uninfested & $0.00 \mathrm{a}$ & $0.00 \mathrm{a}$ & $100.00 \mathrm{~h}$ & $0.00 \mathrm{a}$ & $0.00 \mathrm{a}$ & $100.00 \mathrm{f}$ \\
\hline \multicolumn{7}{|l|}{ 2003-2004 season } \\
\hline 1- Trigonella foenum-graecum L. & $62.94 \mathrm{e}$ & $11.11 \mathrm{c}$ & $25.92 c$ & $22.22 b$ & $2.00 c$ & $84.45 e$ \\
\hline 2- Ammi visnaga L . .(Leaves) & $40.74 d$ & $14.81 \mathrm{~cd}$ & $44.44 d$ & $0.00 \mathrm{a}$ & $0.67 a b$ & $100.00 f$ \\
\hline 3- Glycyrrhiza glabra L. & $29.63 c$ & $22.22 e$ & $11.11 \mathrm{ab}$ & $33.33 c$ & $1.33 \mathrm{bc}$ & $66.67 d$ \\
\hline 4- Eucalyptus globulus labill. & $81.48 \mathrm{~g}$ & $11.11 \mathrm{c}$ & $25.92 c$ & $44.45 d$ & $4.33 e$ & $55.55 c$ \\
\hline 5-Boughoinvillae spectabilis willd. & $40.74 d$ & $22.22 e$ & $48.15 \mathrm{de}$ & $42.44 d$ & $1.33 \mathrm{bc}$ & $55.55 c$ \\
\hline 6- Ammi visnaga L. $\quad$ (Seeds) & $14.81 \mathrm{bc}$ & $14.81 \mathrm{~cd}$ & $70.37 f$ & $0.00 \mathrm{a}$ & $0.33 a$ & $100.00 f$ \\
\hline 7- Salix purpura L. & $74.08 f$ & $18.89 d$ & $7.41 \mathrm{a}$ & $84.45 \mathrm{e}$ & $3.33 d$ & $15.55 b$ \\
\hline 8- Rizolex T-50. & $0.00 \mathrm{a}$ & $14.81 \mathrm{~cd}$ & $85.52 \mathrm{e}$ & $0.00 \mathrm{a}$ & $0.00 \mathrm{a}$ & $100.00 f$ \\
\hline 9- Control : Infested & $85.19 \mathrm{~g}$ & $3.67 \mathrm{~b}$ & $14.81 b$ & $88.89 f$ & $6.67 f$ & $11.11 \mathrm{a}$ \\
\hline 10- Control : Uninfested & $0.00 \mathrm{a}$ & $0.00 \mathrm{a}$ & $100.00 \mathrm{~g}$ & $0.00 \mathrm{a}$ & $0.00 \mathrm{a}$ & $100.00 \mathrm{f}$ \\
\hline
\end{tabular}

Mean followed by the same letter are not significantly different at the $5 \%$ level by DMART 
Table (3): Effect of plant extracts on parameters of plant growth of sugar beet plants, in greenhouse, during 2002-2003 and 20032004 seasons.

\begin{tabular}{|c|c|c|c|c|c|c|}
\hline \multirow[b]{2}{*}{ Treatment } & \multicolumn{3}{|c|}{ 2002-2003 season } & \multicolumn{3}{|c|}{ 2003-2004 seasons } \\
\hline & $\begin{array}{c}\text { Plant } \\
\text { height } \\
(\mathrm{cm})\end{array}$ & $\begin{array}{c}\text { Leaf } \\
\text { area } \\
(\mathrm{cm} 2) \\
\end{array}$ & $\begin{array}{c}\text { Dry } \\
\text { weight } \\
(\mathrm{g}) \\
\end{array}$ & $\begin{array}{c}\text { Plant } \\
\text { height } \\
(\mathrm{cm})\end{array}$ & $\begin{array}{c}\text { Leaf area } \\
(\mathrm{cm} 2)\end{array}$ & $\begin{array}{c}\text { Dry } \\
\text { weight } \\
\text { (g) }\end{array}$ \\
\hline 1 - Trigonella foenum-graecum $\mathrm{L}$. & $45.33 \mathrm{~d}$ & $886.09 \mathrm{~d}$ & $9.73 \mathrm{f}$ & $50.67 \mathrm{c}$ & $857.30 \mathrm{f}$ & $10.83 \mathrm{e}$ \\
\hline 2- Ammi visnaga $\mathrm{L} . \quad$ ( leaves ) & $66.33 \mathrm{a}$ & $1300.21 \mathrm{a}$ & $14.73 \mathrm{a}$ & $59.67 \mathrm{a}$ & $1225.43 \mathrm{a}$ & $13.17 \mathrm{a}$ \\
\hline 3- Glycyrrhiza glabra L. & $38.67 \mathrm{~d}$ & $1013.73 b$ & $11.63 \mathrm{~cd}$ & $34.33 \mathrm{f}$ & $1117.13 \mathrm{c}$ & $11.50 \mathrm{~d}$ \\
\hline 4- Eucalyptus globulus labill. & $46.67 \mathrm{c}$ & $993.37 \mathrm{c}$ & $10.87 d$ & $50.67 \mathrm{c}$ & $1049.34 \mathrm{~d}$ & $10.23 \mathrm{f}$ \\
\hline 5- Boughoinvillae spectabilis willd. & $47.67 \mathrm{c}$ & $989.58 \mathrm{c}$ & $11.87 \mathrm{c}$ & $46.33 d$ & $1068.24 d$ & $11.57 \mathrm{~d}$ \\
\hline 6- Ammi visnaga L.( Seeds) & $56.33 \mathrm{~b}$ & 1248.85 a & $13.60 \mathrm{~b}$ & $53.67 \mathrm{bc}$ & $1174.48 \mathrm{~b}$ & $12.50 \mathrm{bc}$ \\
\hline 7- Salix purpura L. & $38.33 \mathrm{~d}$ & $750.34 \mathrm{e}$ & 9.87 e & $34.00 \mathrm{f}$ & 884.30 e & 10.73 ef \\
\hline 8- Rizolex T-50. & $55.67 \mathrm{~b}$ & $1075.09 \mathrm{~b}$ & $11.73 \mathrm{c}$ & $55.33 \mathrm{~b}$ & $1073.18 d$ & $12.20 \mathrm{c}$ \\
\hline 9- Control : Infest & $39.67 \mathrm{~d}$ & 710.90 ef & 8.70 ef & $32.67 \mathrm{~g}$ & $705.83 \mathrm{~g}$ & $8.27 \mathrm{~g}$ \\
\hline 10- Control : Uninfested & $44.67 \mathrm{c}$ & $906.05 \mathrm{~d}$ & $9.86 \mathrm{e}$ & $39.33 \mathrm{e}$ & $908.47 \mathrm{e}$ & $10.10 \mathrm{f}$ \\
\hline
\end{tabular}

Mean followed by the same letter are not significantly different at the $5 \%$ level by DMRT.

Effect of chemical fractions of $A$. visnaga seeds on the growth of $R$. solani: This study was carried out to find out the chemical fraction of seeds of $A$. visnaga responsible for its effectiveness on the causal pathogen of root rot disease.Major chemical components of seeds of A.visnaga were fractionated into three fractions by three solvents as described under Material \& Methods.FractionNo.IV containing khellin was not evaluated for its effect on the growth of root infecting fungi because of the tinny amount that could be obtained throughout the extraction process. Hence, commercial khellin (Sigma) was experimented as a refernce to the extracted fractions for their effectiviness in retarding the growth of fungi under study.

Data presented in Table (5) indicated that neither diethyl-ether nor potroleum-ether extract affected the growth of fungi under study at any of the concentrations used. Methyl alcohol fraction, however effectively inhibited growth of $R$. solani at all concentrations (efficiency from 13.33 to $21.11 \%$ ) . Results also show that the commercial khellin was highly active in reducing the linear growth of $R$. solani Its effect has been increased gradually by increasing the concentration in PDA from 1000 to 2000 ppm .

Effect of plant extracts and oils on sugar beet root rot incidence : Different plant extracts were studied for their effect on root rot of sugar beet under natural infection at the Farm of Sakha in 2002-2003 and 2003-2004 seasons .

Data presented in Table (6) reveal that plant extracts of A.visnaga \& B.spectabilis were superior than the other materials in reducing the root rot of sugar beet as well as the disease severity in both seasons of experimentation. The yield per plot was found also to be increased due to treatment with these materials. G.glabra, was found to be effective in decreasing the disease incidence $0.63 \%$, but caused an increase in the disease severity $3.67 \%$. Rizolex T 50 caused the least level of infection and disease severity if compared with the other treatments. The yield per plot in A.visnaga (seeds) treatment exceeded the yield $74.00 \%$ obtained from the Rizolex T plots $70.02 \%$ in 2003-2004. 
J. Agric. Sci. Mansoura Univ., 32 (6), June, 2007

T4 
Gouda M. I.

Table 5: Effect of chemical fractions of $A$. visnaga seed, on linear growth of $R$. solani.

\begin{tabular}{|c|c|c|c|c|c|c|c|c|c|c|c|c|c|}
\hline \multirow[b]{3}{*}{ Fungi } & \multicolumn{12}{|c|}{ Chemical fraction \& (concentrations ppm) } & \multirow{3}{*}{ 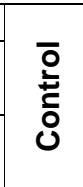 } \\
\hline & \multicolumn{3}{|c|}{ Di ethyl-ether } & \multicolumn{3}{|c|}{$\begin{array}{c}\text { Petroleum- } \\
\text { ether }\end{array}$} & \multicolumn{3}{|c|}{ Methyl alochol } & \multicolumn{3}{|c|}{ Khellin } & \\
\hline & $\begin{array}{l}1000 \\
\text { ppm }\end{array}$ & $\begin{array}{l}1500 \\
\text { ppm }\end{array}$ & $\begin{array}{l}2000 \\
\text { ppm }\end{array}$ & $\begin{array}{l}1000 \\
\text { ppm }\end{array}$ & $\begin{array}{l}1500 \\
\text { ppm }\end{array}$ & $\begin{array}{l}2000 \\
\text { ppm }\end{array}$ & $\begin{array}{l}1000 \\
\text { ppm }\end{array}$ & $\begin{array}{l}1500 \\
\text { ppm }\end{array}$ & $\begin{array}{l}2000 \\
\text { ppm }\end{array}$ & $\begin{array}{l}1000 \\
\text { ppm }\end{array}$ & $\begin{array}{l}1500 \\
\text { ppm }\end{array}$ & $\begin{array}{l}2000 \\
\text { ppm }\end{array}$ & \\
\hline L.G & $9.00 \mathrm{a}$ & $9.00 \mathrm{a}$ & $9.00 a$ & $9.00 \mathrm{a}$ & $9.00 a$ & $9.00 \mathrm{a}$ & $7.80 \mathrm{~b}$ & $7.50 \mathrm{c}$ & $7.10 \mathrm{~d}$ & $6.00 \mathrm{~b}$ & $3.40 c$ & $2 . .5 d$ & $9.00 \mathrm{a}$ \\
\hline E. & 0.00 & 0.00 & 0.00 & 0.00 & 0.00 & 0.00 & 13.33 & 16.66 & 21.11 & 33.33 & 62.22 & 72.22 & 0.00 \\
\hline
\end{tabular}

Means followde by the same letter are not significantly different at the $5 \%$ level by DMRT L.G =Fungal linear growth $(\mathrm{Cm})$. $\quad \mathrm{E}=$ efficiency in reducing colony dimeter\%.

Table (6): Effect of plant extracts on root rot disease under field conditions, Sakha,2002-2003 and 2003-2004 seasons.

\begin{tabular}{|c|c|c|c|c|c|c|}
\hline \multirow[b]{3}{*}{ Treatment } & \multicolumn{3}{|c|}{ 2002-2003 } & \multicolumn{3}{|c|}{ 2003-2004 season } \\
\hline & \multicolumn{2}{|c|}{ Root rot } & \multirow[b]{2}{*}{$\begin{array}{c}\text { Yield/plot } \\
\quad(\mathrm{kg})\end{array}$} & \multicolumn{2}{|c|}{ Root rot } & \multirow[b]{2}{*}{$\begin{array}{c}\text { Yield/plot } \\
\text { (kg) }\end{array}$} \\
\hline & $\begin{array}{c}\text { Disease } \\
\text { incidence } \\
\%\end{array}$ & $\begin{array}{l}\text { Disease } \\
\text { severity }\end{array}$ & & $\begin{array}{c}\text { Disease } \\
\text { incidence } \\
\%\end{array}$ & $\begin{array}{l}\text { Disease } \\
\text { severity }\end{array}$ & \\
\hline 1- Trigonella foenum-graecum $L$. & $4.68 \mathrm{~g}$ & $2.33 \mathrm{~d}$ & $42.00 \mathrm{~d}$ & $2.63 \mathrm{~d}$ & $2.00 \mathrm{e}$ & $50.00 \mathrm{de}$ \\
\hline 2- Ammi visnaga $L . \quad$ (leaves) & $1.24 \mathrm{c}$ & $1.67 \mathrm{c}$ & $52.00 \mathrm{c}$ & $0.57 \mathrm{~b}$ & $0.67 \mathrm{bcd}$ & $56.00 \mathrm{~cd}$ \\
\hline 3- Glycyrrhiza glabra L. & $0.63 \mathrm{~b}$ & $3.67 \mathrm{e}$ & $52.02 \mathrm{c}$ & $0.01 \mathrm{a}$ & $0.33 \mathrm{ab}$ & 46.00 ef \\
\hline 4- Eucalyptus globulus labill. & $1.32 \mathrm{c}$ & $3.33 \mathrm{e}$ & $60.00 \mathrm{ab}$ & $1.49 \mathrm{c}$ & $1.00 \mathrm{~d}$ & $48.00 \mathrm{~d}$ \\
\hline 5-Boughoinvillaea spectablis willd. & $0.58 \mathrm{~b}$ & $1.67 \mathrm{c}$ & $54.00 \mathrm{bc}$ & $0.00 \mathrm{a}$ & $0.01 \mathrm{a}$ & $60.00 \mathrm{bc}$ \\
\hline 6- Ammi visragu L. ( Seeds) & $0.00 \mathrm{a}$ & $0.01 \mathrm{a}$ & $64.00 \mathrm{a}$ & $0.01 \mathrm{a}$ & $0.01 \mathrm{a}$ & $74.00 \mathrm{a}$ \\
\hline 7- Salix purpura L. & $3.19 f$ & $2.50 \mathrm{~d}$ & $40.00 \mathrm{de}$ & $3.61 \mathrm{~d}$ & $2.67 \mathrm{f}$ & $42.00 \mathrm{f}$ \\
\hline 8- Rizolex T-50 * & $0.63 \mathrm{~b}$ & $0.20 \mathrm{a}$ & $64.00 \mathrm{a}$ & $0.65 \mathrm{~b}$ & $0.50 \mathrm{bc}$ & $70.02 \mathrm{ab}$ \\
\hline 9- Control & $8.05 \mathrm{~h}$ & $3.67 \mathrm{e}$ & $36.00 \mathrm{e}$ & $9.32 \mathrm{e}$ & $3.67 \mathrm{~g}$ & $34.00 \mathrm{~g}$ \\
\hline
\end{tabular}

Means followde by the same letter are not significantly different at the $5 \%$ level by DMRT.

\section{DISCUSSION}

Trials were conducted to study the possibility of controlling sugar beet damping-off and root rot by extracts from some medicinal and aromatic plant parts. PDA treated with plant extracts inhibited growth of the fungal isolates under study. Extracts could successfully reduce damping off and root rots of sugar beet in the greenhouse and field. Yield per plot was also significantly increased due to these applications. Seed extract from Ammi visnaga (tooth pick plant) was shown to be superior to all materials in suppressing damping off and root rots in greenhouse and field. Its positive effect against sugar beet root disease reflects, in turn on the root yield, whereas, it improved the yield potentiality comparable to the untreated control.

Parameters of plant growth were enhanced due to these treatments. Increasing in total soluble sugars (TSS) and sugar purity in roots due to these applications were observed. This result causes, in turn an improve to the sugar quality within the roots. These results are consistent with those 
obtained by other investigators who found an antimicrobial activity of some plant extracts against many of pathogens in vitro Mc Cutcheon et al., (1994) and Navarro et al.,(1996). Some higher plant extracts have an allelopathic effect on some diseases on other plant hosts as previous investigators have reported El-Shoraky(1998);Fahmy\& Mahmoud,(2001) and Gouda, (2001).

Based on the obtained rusltus, extracts from seeds of tooth picks (ammi visnaga) is recommend able to use in controlling the major pathogens of the root rot of sugarbeet.This extract offer an excellent sourse of biologically active natural product through its allelopathic effect. Allelopathy, as defined by Rice,(1984) and El-Kazzaz et al., (2003) is any direct or indirect benficial or harmful effect of one organism (including plant or microorganism) through release of chemicals into the environment. English name of this medicinal plant is Pick-tooth, Tooth-pick and Bishop's weed. It is grown mainly in the Nile region and unknown chemical compounds having synergistic effect on the in some other countries. Seeds of this medicinal plant are available and cheap in local market. Active constituents that have the allelopathic effect of A.visnaga seeds according to Batanouny, et al., (1999) are the furanochromones comprising 0.3-1.2 \% khellin, 0.05-0.3\% visnagin. Present study showed the high activity of methyl extract (containing the visnagin fraction) as well as the commercial substance of khellin in retarding the radial growth of root pathogens. This confirms and explains the active role of visnagin and khellin in reducing the seedling damping-off and root rot of sugar beet. Positive effect of the toxic substances in extracts of seeds of A.visnaga (and other higher plant extracts used in this study) may be attributed to the known and pathogen. Besides, they may affect the populations of soil microflora around the host roots which may cause, in turn a rise of antagonistic and biological agents. Therefore, the author recommends, in the time being to soak seed of sugar beet with extract of A.visnaga for $8 \mathrm{~h}$ before planting (need further study for reasonable means of application). It is worth mentioning that using other means of disease control rather than fungicides is strongly encouraged by the government to decrease environmental pollution caused by chemical fungicides.

\section{REFEREANCES}

A.O.A.C., Association of Official Analytical Chemists (1990). Official methods analysis of the association of official analytical chemists. Washington. 25. D.C. USA.

Batanouny, K.H.; E. Aboutabl; M. Shabana and F. Soliman (1999). Wild Medicinal Plants in Egypt. Academy of Scientific Research and Technology, Egypt,207 pp.

Chiej, R. (1988). The Macdonald Encyclopedia of Medicinal Plants Macdonald \& Co (Publishers) Lid, London, 447p. Zeitschrift Fur pfllanzenkrar kheiten und pflanzenschutz 98 (5): 539-546.

El-Abyad, M.S. ; A.M. Abu-Taleb and M.S. Khalil (1992). Impact of salinity stress on soil borne fungi of sugar beet III. Plant cell wall-degrading 
Gouda M. I.

enzymes by Rhizoctonia solani Kuhn and Sclerotium rolfsii Sacc. In vivo and In vitro. Plant soil, 143(1): 75-83.

El-Kazzaz, M.K. ; M.A. Hassan ; M.M. Badr and K.E. Ghoniem (1999). Studies on sugar beet root diseases in Northern Nile Delta. J. Agric. Res., Tanta Univ., 25 (2): 122-131.

El-Kazzaz, M.K.; El-Assiuty; E. M. Badr, M. M. El-Zahaby, and Gouda, M. I. (2003). Effect of some plant extracts and essential oils on controlling sugar root rot disease caused by Sclerotium rolfsii Sacc. In proceedings of the $10^{\text {th }}$ Congress of the Egyptian Phytopathological Society, 9-10 Dec. 2003, Giza, Egypt.

El-Kholi, M.M.A. (2000). Sugar beet diseases in Egypt. The Ninth Conference of Phytopathology. The Egypt. Phytopathol. Soc., Giza, Egypt, May 2000.

El-Shoraky, Fathia, S.A.(1998).Using extracts and oils of some plants in controlling plant diseases. Ph.D.Thesis, Fac.of Agric.Kafr ElSheikh,Tanta University, $187 \mathrm{pp}$.

Gouda. M.I. (2001). Studies on some causes of sugar beet root rots. Ph.D. Thesis, Fac. of Agric., Tanta Univ. Egypt. p. 146.

Grainger, J. (1949). Crops and diseases. Dept. PI. Pathol., W. Scotland Agric. Coll. Auchineruire, Res., Bull No. 9 pp. 51.

Fahmy, Zeinab. M. and Mahmoud, Amal. H. (2001). Allelopathy of Eucalptus rostrata leaves in controlling late-wilt Disease of Maize. Egypt. J. Appl. Sci., 16 (4) 62-74.

Mangamma, P. and A. Sreeramulu (1991). Garlic extract inhibitory to growth of Xanthomonas campestris pv. vesicatoria.Indian Phytopathology, 44 (3):372-374.

Mc Cutcheon, A.R. ; S.M. Ellis ; R.E.W. ;Hancock and G.H.N. Towers. (1994). Antifungal screening of medicinal plant of British Columbian native peoples. Journal of Ethnopharmacology, 44 (3): 157-169

Mc Ginnis, R.A. (1982). Beet sugar technology. $3^{\text {rd }}$ edn. Beet sugar development Foundation for Collins, $855 \mathrm{pp}$.

Navarro, V. ;M.L. Villarreal ; G. Rojas and X. Lozoya. (1996). Antimicrobial evaluation of some plants used in Mexican traditonal medicine for the treatment of infectious diseases. Journal of Ethnopharmacology, 53 (3): 143-147.

Rice, E.L. (1984). Allelopathy. $2^{\text {nd }}$ edn Academic Press, New York. 422p. 
تأثير بعض المستخلصات النباتية على مقاومـة مـوت البادرات و عفن جذور بنجر

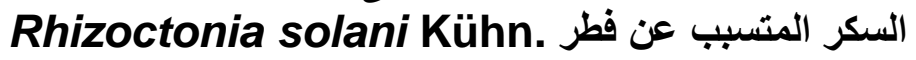

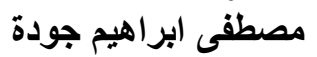
معهد بحوث امراض النباتات ـ مركز البحوث الزراعية ـ الجيزة ـ مصر

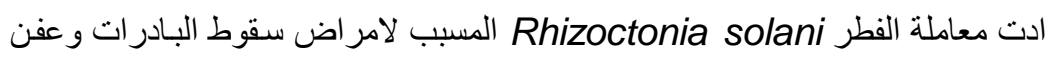

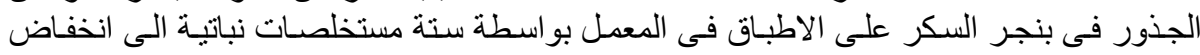

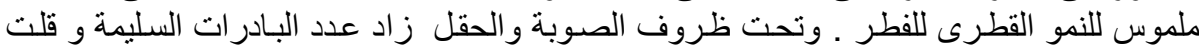

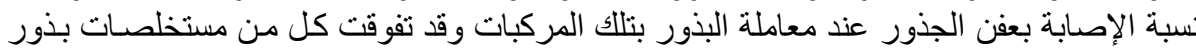

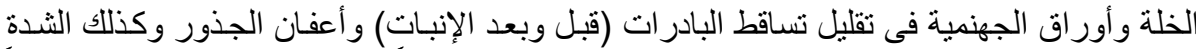

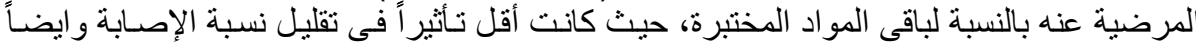

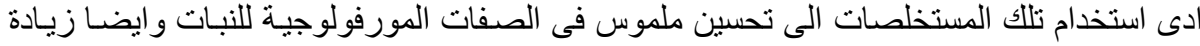

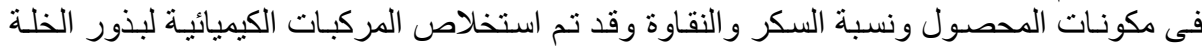

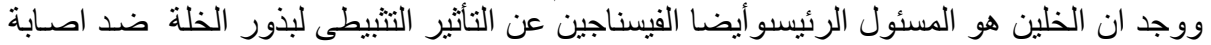

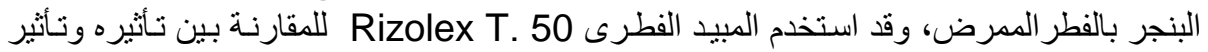
تللك المستخلصات المختبرة فى قدرتها على مقاومة امر اض البادرات وعفن الجذور المنسبب عن هذا لـاتير الفطر الف 
Table 4 . Effect of plant extracts on root rot, root weight/plant percentage of total soluble solids (TSS), percentage of sucrose, purity and losses (\%) in yield and sucrose of sugar beet root rot under artificial infestation with $R$. solani, under greenhouse,2002-2003 and 2003-2004 seasons

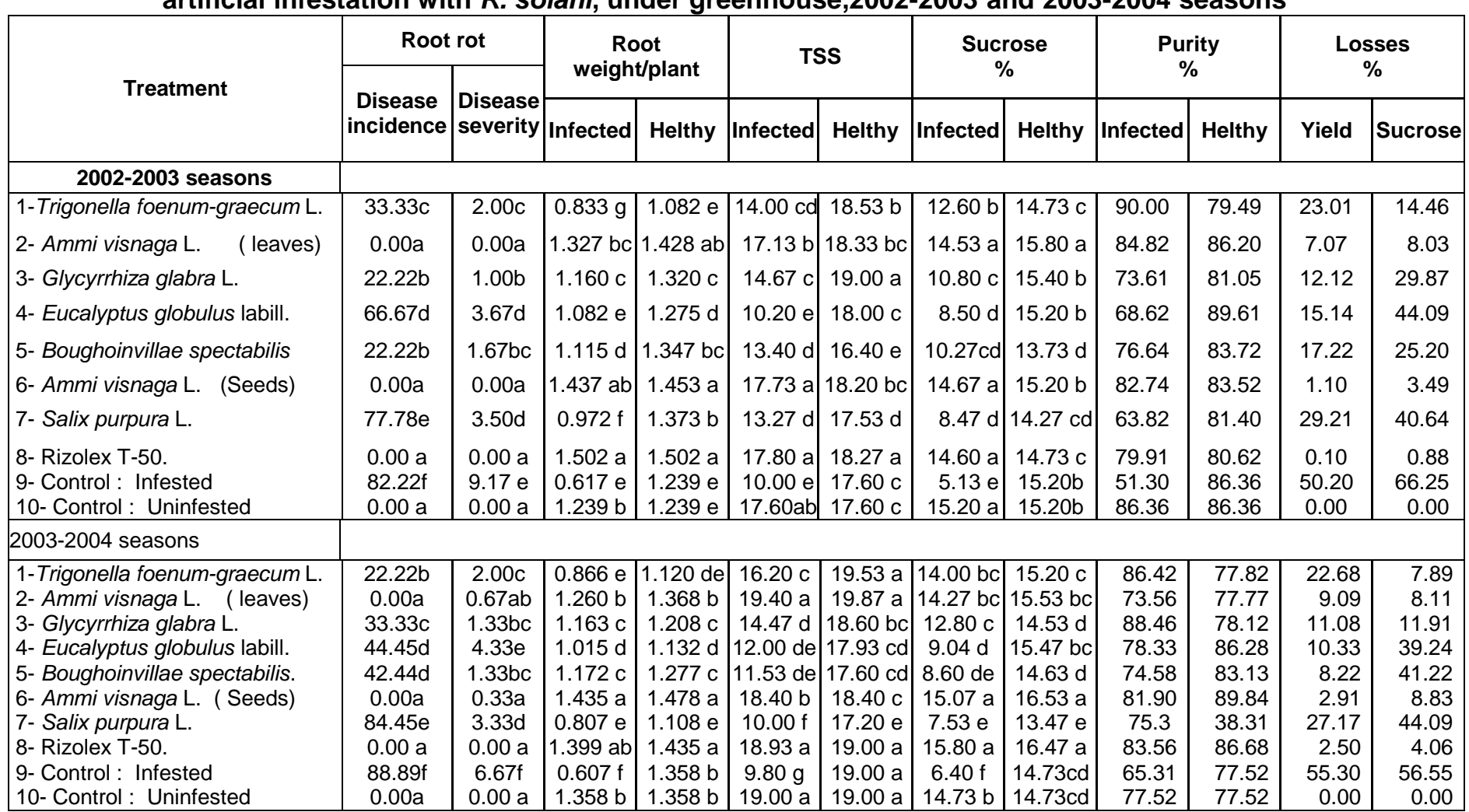

Mean followed by the same letter are not significantly different at the $5 \%$ level by DMRT. 